\title{
Molecular detection of Leishmania infantum in donkeys and mules under semiarid conditions in Brazil
}

\author{
Detecção molecular de Leishmania infantum em asininos e muares sob \\ condições semiáridas
}

\begin{abstract}
Clécio Henrique Limeira1* (1D; Murilo Duarte de Oliveira²; João Pessoa Araújo Júnior³; Camila Dantas Malossi³; Leila Sabrina Ullmann³; Maria Luana Cristiny Rodrigues Silva; Sérgio Santos de Azevedo; Clebert José Alves ${ }^{1}$

1Programa de Pós-graduação em Ciência e Saúde Animal, Centro de Saúde e Tecnologia Rural, Universidade Federal de Campina Grande - UFCG, Patos, PB, Brasil

${ }^{2}$ Instituto Federal do Sertão Pernambucano, Salgueiro, PE, Brasil

${ }^{3}$ Universidade Estadual Paulista - UNESP, Botucatu, SP, Brasil
\end{abstract}

How to cite: Limeira CH, Oliveira MD, Araújo Júnior JP, Malossi CD, Ullmann LS, Silva MLCR, et al. Molecular detection of Leishmania infantum in donkeys and mules under semiarid conditions in Brazil. Braz J Vet Parasitol 2021; 30(4): e015021. https:// doi.org/10.1590/S1984-29612021095

\begin{abstract}
Visceral leishmaniasis is a parasitic zoonosis that mainly affects poorest and most vulnerable populations, and domestic dogs are considered to be the main source of infection to the vector and therefore humans. However, several studies have investigated the role of other vertebrate hosts in the disease cycle. In this context, the aim of the present study was to conduct a survey of Leishmania infantum infection in donkeys and mules living in a semiarid region of Brazil. Whole blood sampled from 72 equids ( 65 donkeys and 7 mules) was used to perform molecular diagnosis using the real-time polymerase chain reaction (qPCR) technique. A total of $25 \%$ of the samples $(18 / 72)$ were positive through qPCR, but there were no significant differences between the species (donkeys or mules), sex (male or female) and abandonment situation of the animals (yes or no). Donkeys and mules living under semiarid conditions have high frequency of $L$. infantum infection. It is therefore worth assigning importance to these species in the epidemiological cycle of visceral leishmaniasis, either as potential reservoirs or just as an abundant food source for vectors.
\end{abstract}

Keywords: Epidemiology, equids, leishmaniosis, qPCR, zoonosis.

\section{Resumo}

A leishmaniose visceral é uma zoonose parasitária que afeta principalmente populações mais pobres e vulneráveis, e os cães domésticos são considerados as principais fontes de infecção para o vetor e, portanto, para os humanos. Porém diversos estudos têm pesquisado o papel de outros hospedeiros vertebrados no ciclo da doença. Neste contexto, objetivou-se realizar um levantamento da infecção por Leishmania infantum em asininos e muares, vivendo em região semiárida do Brasil. Foi utilizado sangue total de 72 equídeos (65 asininos e 7 muares) para a realização de diagnóstico molecular por meio da técnica de Reação em Cadeia de Polimerase em Tempo Real (qPCR). Um total de $25 \%$ das amostras (18/72) resultaram positivas na $\mathrm{QPCR}$, porém não houve diferença significativa entre as espécies (asininos e muares), sexo (macho e fêmea) e situação de abandono dos animais (sim ou não). Asininos e muares, vivendo em condições semiáridas, apresentam alta frequência de infecção por L. infantum, sendo válido atribuir importância a essas espécies no ciclo epidemiológico da leishmaniose visceral, seja como um reservatório em potencial, seja apenas como uma fonte alimentar abundante para os vetores.

Palavras-chave: Epidemiologia, equídeos, leishmaniose, qPCR, zoonose. 


\section{Introduction}

Leishmaniases are parasitic zoonosis caused by several species of the genus Leishmania, endemic in many regions of the world, especially in underdeveloped and developing countries. They are considered be a neglected disease that affects the poorest and most vulnerable populations that do not have adequate access to healthcare services (WHO, 2017).

In areas that are endemic for visceral leishmaniasis, domestic dogs have been reported as the main source of infection to the vector and, therefore, humans (Pace, 2014). However, several studies have demonstrated the possibility that other vertebrate hosts might harbor parasites and participate in the disease cycle (Quaresma et al., 2011; Gao et al., 2015; Kenubih et al., 2015; Rohousova et al., 2015). In this regard, Limeira et al. (2019) conducted a systematic analysis on several studies that indicated the presence of different Leishmania species, such as $L$. braziliensis, L. infantum and L. siamensis parasitizing donkeys, horses and mules. This may suggest that the parasites are adapting to these new hosts (Soares et al., 2013). In equids, the clinical manifestations described so far have comprised a benign cutaneous form of the disease, with lesions observed at the inoculation site, of self-limiting nature (Limeira et al., 2019).

Semi-arid regions of emerging countries generally have low rates of socioeconomic development, which leads the population of these areas to indiscriminately exploit the natural resources of native vegetation (Silva et al., 2016b). This gives rise to environmental imbalance that can influence the epidemiological aspects of vector-borne diseases such as dengue, leishmaniases and Chagas disease. In addition, the functions previously performed by equids in these regions have been replaced by forms of mechanical traction, which has resulted in abandonment of these animals and uncontrolled population growth, especially of donkeys (Carneiro et al., 2018). In periods of drought, these abandoned animals can move close to homes in search of food, water and/or shelter, which increases the food sources for phlebotomines (sandflies) in peridomestic environments. This can generate a risk of infection by Leishmania spp. in the population of these areas.

Thus, considering the specific characteristics of semiarid regions, the increasing numbers of abandoned equids and the proximity of the population to these animals, the objective of this study was to conduct a survey of $L$. infantum infection among donkeys and mules living under semiarid conditions.

\section{Material and Methods}

The procedures developed in this study were previously submitted to and analyzed by the Ethics Committee for Animal Use of the Health and Rural Technology Center, Federal University of Campina Grande (CEUA/CSTR/ UFCG), in accordance with the current rules and regulations, and the protocol approved was registered under the number 011/2019.

\section{Study area}

This study was conducted in rural areas of the municipality of Salgueiro $\left(8^{\circ} 4^{\prime} 20^{\prime \prime} \mathrm{S} ; 39^{\circ} 7^{\prime} 36^{\prime \prime} \mathrm{W}\right)$, in the semiarid region of the state of Pernambuco, northeastern Brazil. This municipality has a human development index (HDI) of 0.669 (IBGE, 2020) and is considered endemic for human visceral leishmaniasis (Brasil, 2021).

\section{Animals, clinical evaluation and sampling}

Through non-probabilistic sampling, for convenience, a total of 72 equids ( 65 donkeys and 7 mules) living in rural areas of the municipality of Salgueiro were included in the study. Both animals living under the care of owners, with shelter and food provided, and animals in situations of abandonment, without fixed shelter and living freely off the local vegetation (Caatinga), were evaluated. The latter were captured using lassoes, by a trained and experienced person. This study was developed during the months of October 2018 and March 2019.

From each animal, $4 \mathrm{~mL}$ of whole blood were collected directly from the jugular vein using a vacuum tube containing EDTA. The samples were then packed in Styrofoam boxes with ice and sent to the laboratory, where they were frozen and kept at a temperature of $-20^{\circ} \mathrm{C}$ until the time of use. At the time when the animals were being restrained for blood collection, they animals were evaluated by means of visual inspection and palpation, seeking to observe any possible skin lesions. 


\section{Molecular diagnosis}

Genetic material, i.e. deoxyribonucleic acid (DNA), was extracted from the samples by means of the DNeasy blood and tissue kit (Qiagen ${ }^{\circledR}$, Hilden, Germany), using an aliquot of $180 \mu \mathrm{L}$ of the whole blood, following the manufacturer's recommendations. A qualitative real-time polymerase chain reaction (qPCR) was performed as previously described by Silva et al. (2016a), using the primers Linf kDNA-F 5'-GGCGTTCTGCAAAATCGGAAA-3', Linf kDNA-R 5'-CCGATTTTTGGCATTTTTGGTCGAT-3' and Linf kDNA_FAM-5'- TTTTGAACGGGATTTCTG-3' in order to amplify the kinetoplast minicircle gene (KDNA) of $L$. infantum. A culture of $L$. infantum was used as a positive control, and ultrapure water was used as a negative control.

Samples that were found to be positive through qPCR were then sequenced by means of conventional PCR for L. infantum, using the following specific 447-base primers, with a larger amplification fragment of the kinetoplast minicircle gene (kDNA): MC1 (5'-GTTAGCCGA TGGTGGTTTG-3') and MC2 (5'-CACCCATTTTTCCGATTTG-3') (Cortes et al., 2004; Benassi et al., 2018), following the methodology of Benassi et al. (2018).

The sequencing reaction was performed with the MC1 and MC2 primers described above, using the Big Dye Terminator v3.1 cycle sequencing kit (Applied Biosystems, Foster City, CA, USA). Capillary electrophoresis was performed using the Genetic Analyzer 3130 and POP-7 polymer (Applied Biosystems), as described by Platt et al. (2007).

Nucleotide sequences were elaborated using the Sequencing Analysis software v5.3.1 (Applied Biosystems), constructed and aligned using the BioEdit software (Hall, 1999). These sequences were then compared with $L$. infantum strains obtained from GenBank (National Center for Biotechnology Information, Bethesda, MD, USA) (http://www.ncbi.nlm.nih.gov/BLAST/).

A phylogenetic tree was generated using the o software Seaview4 (Gouy et al., 2010), in which its tree was built using the Bio Neighbor-Joining method and Kimura $2 p$ model bootstrap with 1,000 repetitions. This was visualized through FigTree v1.4.4 (http://tree.bio.ed.ac.uk/). Phylogenic reconstruction included sequences of Leishmania for comparison.

\section{Statistical analysis}

Prevalence ratios were used to measure effects (Coutinho et al., 2008) and Fisher's exact test (with significance level of 5\%) was used to investigate the existence of associations between the dependent variable and the independent variables (species, sex and abandonment situation), using the "epiR" package (Stevenson et al., 2020) in the statistical program R, version 3.5.1 (R Core Team, 2020).

\section{Results}

Out of the total number of samples analyzed, $25 \%$ (18/72) presented genetic material of L. infantum in peripheral blood according to the $\mathrm{qPCR}$ technique. However, none of the animals demonstrated any visible clinical alterations at the time of the sampling.

In analyses on the data according to categories, $23.08 \%$ (15/65) of the donkeys and $42.86 \%(3 / 7)$ of the mules were positive; regarding sex, $22.62 \%(12 / 53)$ of the males and $31.58 \%(6 / 19)$ of the females were positive; and regarding the abandonment situation, $35.29 \%$ (6/17) of the animals in this condition and $21.82 \%(12 / 55)$ of those who were not in this condition tested positive in $\mathrm{PPCR}$, but without any statistical differences between the categories (Table 1).

Because of the low quantity of amplicons, it was only possible to sequence genetic material from one of the positive samples. The phylogenetic tree thus constructed demonstrated that the L. infantum found in this sample had evolutionary relationships with others available in GenBank (Figure 1).

\section{Discussion}

Leishmania spp. infection has been described in equids in various regions of the world, with a combined global prevalence of $25 \%$ (Cl 15-35\%), according to a meta-analysis conducted by Limeira et al. (2019). That prevalence was equal to what was found in this study for $L$. infantum infection. Other studies that used molecular tests (PCR) have also indicated that $L$. infantum is able to infect significant percentages of equids: Gao et al. (2015) described a prevalence of $21.63 \%$ in the Jiashi desert, China; Benassi et al. (2018) found a prevalence of $15 \%$ in healthy horses 
Table 1. Frequency by category (species, sex and abandonment status) of L. infantum detected through qPCR in donkeys and mules living under semiarid conditions in Brazil.

\begin{tabular}{|c|c|c|c|c|c|}
\hline Variables & Categories & $\begin{array}{l}\text { Number of } \\
\text { animals }\end{array}$ & Positives (\%) & $\begin{array}{c}\text { Prevalence Ratio } \\
\text { (CI 95\%) }\end{array}$ & p-value* \\
\hline \multirow[t]{2}{*}{ Species } & Mules & 65 & $15(23,08)$ & $1,86(0,71-4,87)$ & 0,356 \\
\hline & Donkeys & 7 & $3(42,86)$ & & \\
\hline \multirow[t]{2}{*}{ Sex } & Males & 53 & $12(22,64)$ & $1,39(0,61-3,19)$ & 0,539 \\
\hline & Females & 19 & $6(31,58)$ & & \\
\hline \multirow{2}{*}{$\begin{array}{l}\text { Abandonment } \\
\text { situation }\end{array}$} & Yes & 55 & $12(21,82)$ & $1,62(0,72-3,66)$ & 0,338 \\
\hline & No & 17 & $6(35,29)$ & & \\
\hline Overall & & 72 & $18(25)$ & - & - \\
\hline
\end{tabular}

*Fisher's exact test ( $\mathrm{a}=5 \%)$.

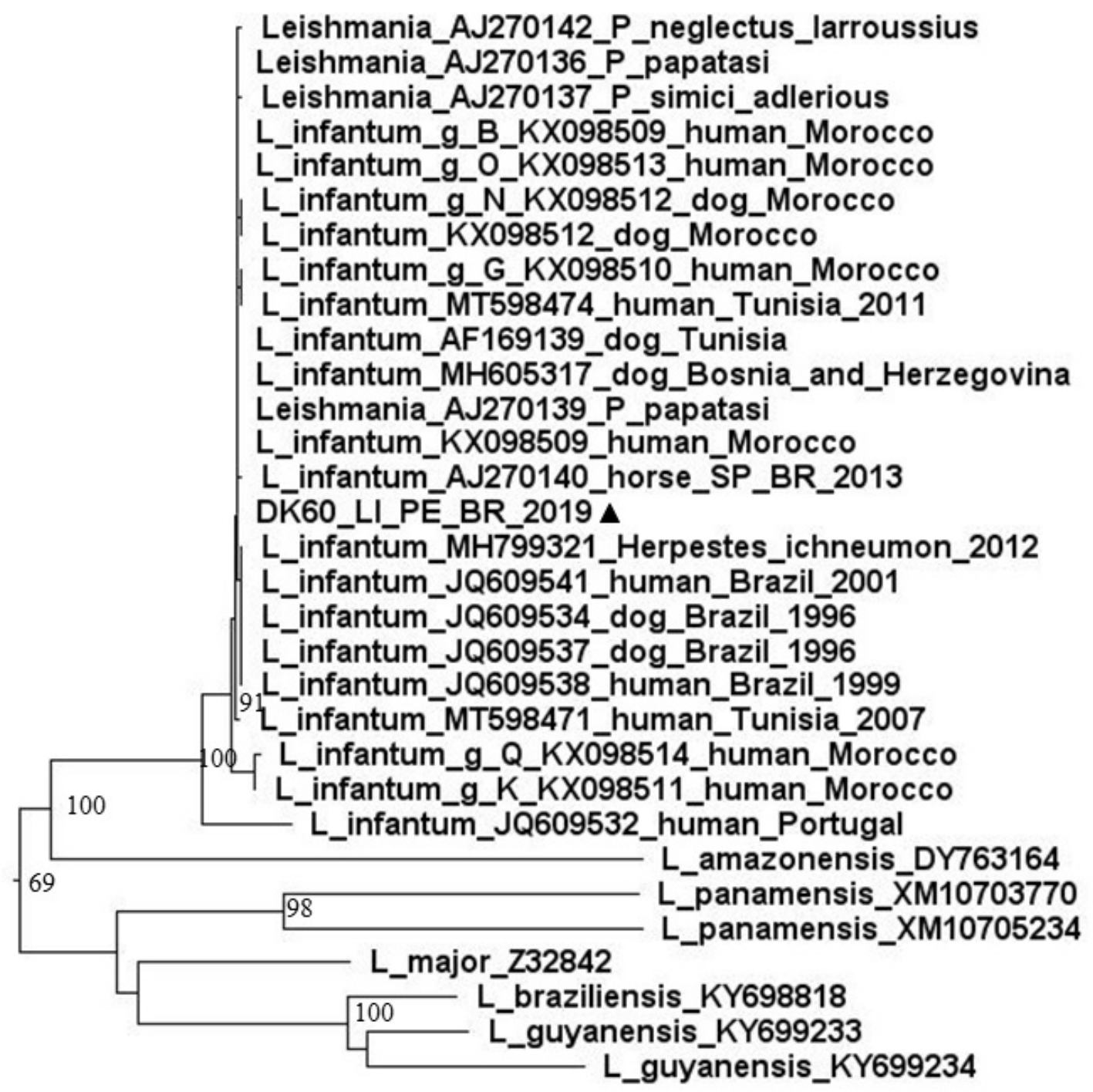

$\boldsymbol{\Delta}$ - Sequenced sample $\quad-\frac{}{0.08}$

Figure 1. Phylogenetic analysis on L. infantum detected in peripheral blood samples from donkeys, constructed through the Bio Neighbor-Joining method and Kimura 2p model bootstrap with 1,000 repetitions. 
and Escobar et al. (2019) reported a prevalence of $14.3 \%$ in southeastern and southern Brazil. These findings suggest that these domestic animals participate in the visceral leishmaniasis cycle. It is interesting to note that in these studies cited, most of the infected equids did not present apparent clinical manifestations (Gao et al., 2015; Benassi et al., 2018); while in others, clinical signs such as cutaneous lesions, nodules and lymphadenopathy could be seen. This was similar to the findings among dogs living in areas of occurrence of visceral leishmaniasis in southern Brazil (Escobar et al., 2019).

Several techniques with different methodologies have been described, both for the purposes of cross-sectional prevalence studies (Truppel et al., 2014; Aharonson-Raz et al., 2015; Evers et al., 2017; Nardoni et al., 2019) and for making clinical diagnoses of skin diseases involving Leishmania spp. infection. (Müller et al., 2009; Soares et al., 2013; Menezes et al., 2019). The results have been heterogeneous, especially those from serological tests, due to the methodological variations used (Limeira et al., 2019). Molecular techniques have become increasingly popular within research, however, despite being very effective for making the diagnosis of leishmaniases (Galluzzi et al., 2018), these techniques still have a high cost, which makes it unfeasible to use them on a larger scale, such as in prevalence studies.

Over the five-year period from 2015 to 2019, 41 cases of human visceral leishmaniasis were recorded in the municipality where the present study was conducted. This represented $4.77 \%$ of the total number of cases reported throughout the state of Pernambuco during this period (Brasil, 2021), thus demonstrating that the disease in humans is endemic in this region. Therefore, the detection of genetic material of $L$. infantum in $25 \%$ of the samples analyzed is a worrying finding, as it indicates that donkeys and mules living in rural areas of the semiarid region of Brazil are exposed to the vector Lutzomyia longipalpis and are frequently infected. This suggests that parasites of the genus Leishmania are becoming adapted to these hosts (Soares et al., 2013).

From analysis on the data according to categories (Table 1), the crude frequency was higher among mules, females and animals in abandonment situations, although no statistical differences between the categories was detected when using the Fisher test $(p>0.05)$. However, these statistical analyses should be interpreted with caution, considering the limitations imposed by the small quantity of samples collected, due to the low number of animals found during visits to farms and the difficulty in capturing the abandoned animals.

Our finding that these equids did not present clinical signs suggestive of leishmaniases at the time of blood collection was in line with data from several other studies (Sgorbini et al., 2014; Oliveira et al., 2017; Benassi et al., 2018; Nardoni et al., 2019). This demonstrating that even when infected, these animals remain asymptomatic, which contributing to the idea that in these hosts, the immune response that is mounted is effective against parasites (Fernández-Bellon et al., 2006). On the other hand, in some reports on cutaneous leishmaniases in horses, lesions arise or progress when females are pregnant and regress immediately after delivery or abortion. Likewise, use of immunotherapy may aggravate the clinical picture of the disease, thus indicating that stressful factors reduce the immune response to infection (Barbosa-Santos et al., 1994; Müller et al., 2009; Reuss et al., 2012). Therefore, further research is needed in order to better analyze this immune response in equids and to try to understand at what point in the life of these hosts their protection levels would decrease to a level that would allow emergence of clinical signs and the possibility of transmission of the protozoa to other hosts. If such situations can develop, these equids would then fit within the concept of "reservoir hosts", as described by Ashford (1996).

According to Ashford (1996), merely identifying hosts that are infected by Leishmania spp. is not enough to define them as reservoirs. Certain ecological factors relating to the hosts are particularly important for enabling them to become reservoirs, such as their geographical distribution and habitat, and the local climate, as well as host population age structure, density, dispersion, movements and social structure. The donkeys and mules used in this study present many of these characteristics, given that they can be found both in urban and in rural areas; their population density has increased significantly, due to abandonment and uncontrolled reproduction (Carneiro et al., 2018); and they move over long distances in their search for food and water. They are therefore exposed to the vectors that are present in a considerably large region.

However, to be characterized as a reservoir host, an infected individual must possess the ability to infect at least one other individual, on average (Ashford, 1997), and this requirement has not yet been reported for equids. Experimentally, Cerqueira et al. (2003) infected four females of Equus asinus aged 3 to 4 months with an inoculum of $10^{8}$ promastigote forms of L. chagasi (synonym L. infantum) (strain IOCLC2455) per kg of body weight, intravenously. However, in xenodiagnoses at follow-ups conducted 2, 4, 6, 8, 10 and 12 months later, the researchers did not recover any flagellated forms of the parasite in females of Lu. longipalpis. This suggested that donkeys are devoid of importance as a reservoir in the transmission chain for visceral leishmaniasis (Cerqueira et al., 2003). 
However, the above-mentioned experiment used promastigote forms, which have low infectivity in relation to amastigote forms, and was based on data (dose and route of administration of the inoculum) from previous studies on dogs, due to the lack of research on the species E. asinus. Thus, further research should be done taking into account important ecological factors such as population density and the proximity of these animals to dogs in peridomestic environments. Studies on invertebrate vectors in semiarid regions and on the immune response levels of donkeys and mules to $L$. infantum infection should also be conducted.

\section{Conclusion}

Donkeys and mules living under semiarid conditions present high frequency of L. infantum infection, and their habits of life allow them to present some characteristics necessary to become a reservoir for the disease. However, investigations on specific characteristics of these species in semiarid environments are needed. Although transmission of infection from parasitized equids has not yet been proven, it is worth ascribing some importance to donkeys and mules in the epidemiological cycle of visceral leishmaniasis in the semiarid region of northeastern Brazil, either as potential reservoirs or just as an abundant food source for vectors, which in the end converge for introduction, reintroduction or increase of cases of the disease in a given region.

\section{Acknowledgements}

The authors are grateful to the Federal Institute of Education, Science and Technology of the Pernambuco Sertão (IFSertão-PE), the Association of Goat and Sheep Breeders of Salgueiro (ASCOSAL) and André Felipe da Silva, for the logistical support necessary for development of this research.

\section{References}

Aharonson-Raz K, Baneth G, Lopes AP, Brancal H, Schallig H, Cardoso L, et al. Low seroprevalence of Leishmania infantum and Toxoplasma gondii in the horse population in Israel. Vector Borne Zoonotic Dis 2015; 15(12): 726-731. http://dx.doi.org/10.1089/ vbz.2015.1826. PMid:26580094.

Ashford RW. Leishmaniasis reservoir and their significance in control. Clin Dermatol 1996; 14(5): 523-532. http://dx.doi. org/10.1016/0738-081X(96)00041-7. PMid:8889331.

Ashford RW. What it takes to be a reservoir host. Belg J Zool 1997; 127(1): 85-90.

Barbosa-Santos EG, Marzochi MC, Urtado W, Queirós F, Chicarino J, Pacheco RS. Leishmaniasis disseminated by Leishmania braziliensis in a mare (Equus cabalus) immunotherapy and chemotherapy assays. Mem Inst Oswaldo Cruz 1994; 89(2): 217-220. http://dx.doi.org/10.1590/S0074-02761994000200018. PMid:7885248.

Benassi JC, Benvenga GU, Ferreira HL, Soares RM, Silva DT, Pereira VF, et al. Molecular and serological detection of Leishmania spp. in horses from an endemic area for canine visceral leishmaniasis in southeastern Brazil. Pesq Vet Bras 2018; 38(6): 10581063. http://dx.doi.org/10.1590/1678-5150-pvb-5214.

Brasil. Ministério da Saúde. Banco de dados do Sistema Único de Saúde - DATASUS. Casos confirmados de leishmaniose visceral, Pernambuco, Brasil, segundo o município de residência entre 2015 e 2019. [online]. Brasil: DATASUS; 2021 [cited 2021 Mar. 20]. Available from: http://tabnet.datasus.gov.br/cgi/tabcgi.exe?sinannet/cnv/leishvpe.def.

Carneiro GF, Lucena JEC, Barros LO. The current situation and trend of the donkey industry in south america. J Equine Vet Sci 2018; 65: 106-110. http://dx.doi.org/10.1016/j.jevs.2018.03.007.

Cerqueira EJL, Sherlock I, Gusmão A, Barbosa AAB Jr, Nakatani M. Inoculação experimental de Equus asinus com Leishmania chagasi Cunha \& Chagas, 1937. Rev Soc Bras Med Trop 2003; 36(6): 695-701. http://dx.doi.org/10.1590/S0037-86822003000600009. PMid:15049109.

Cortes S, Rolão N, Ramada J, Campino L. PCR as a rapid and sensitive tool in the diagnosis of human and canine leishmaniasis using Leishmania donovani s.I. - specific kinetoplastid primers. Trans R Soc Trop Med Hyg 2004; 98(1): 12-17. http://dx.doi.org/10.1016/ S0035-9203(03)00002-6. PMid:14702834.

Coutinho LMS, Scazufca M, Menezes PR. Métodos para estimar razão de prevalência em estudos de corte transversal. Rev Saúde Pública 2008; 42(6): 992-998. http://dx.doi.org/10.1590/S0034-89102008000600003. PMid:19009156. 
Escobar TA, Dowich G, Santos TP, Zuravski L, Duarte CA, Lübeck I, et al. Assessment of Leishmania infantum infection in equine populations in a canine visceral leishmaniosis transmission area. BMC Vet Res 2019; 15: 381. http://dx.doi.org/10.1186/s12917019-2108-1. PMid:31666069.

Evers F, Ferreira FP, Navarro IT, Mitsuka-Breganó R, Pagliari S, Monica TC, et al. Presence of anti-Leishmania spp. antibodies in slaughter horses in Brazil. Semina: Ciênc Agrár 2017; 38(6): 3921-3926. http://dx.doi.org/10.5433/1679-0359.2017v38n6p3921.

Fernández-Bellon H, Solano-Gallego L, Bardagí M, Alberola J, Ramis A, Ferrer L. Immune response to Leishmania infantum in healthy horses in Spain. Vet Parasito/ 2006; 135(2): 181-185. http://dx.doi.org/10.1016/j.vetpar.2005.09.007. PMid:16213661.

Galluzzi L, Ceccarelli M, Diotallevi A, Menotta M, Magnani M. Real-time PCR applications for diagnosis of leishmaniasis. Parasit Vectors 2018; 11(1): 273. http://dx.doi.org/10.1186/s13071-018-2859-8. PMid:29716641.

Gao CH, Wang JY, Zhang S, Yang YT, Wang Y. Survey of wild and domestic mammals for infection with Leishmania infantum following an outbreak of desert zoonotic visceral leishmaniasis in Jiashi, people's Republic of China. PLoS One 2015; 10(7): e0132493. http:// dx.doi.org/10.1371/journal.pone.0132493. PMid:26177101.

Gouy M, Guindon S, Gascuel O. SeaView version 4: a multiplatform graphical user interface for sequence alignment and phylogenetic tree building. Mol Biol Evol 2010; 27(2): 221-224. http://dx.doi.org/10.1093/molbev/msp259. PMid:19854763.

Hall TA. BioEdit: a user-friendly biological sequence alignment editor and analysis program for Windows 95/98/NT. Nucleic Acids Symp Ser 1999; 41: 95-98.

Instituto Brasileiro de Geografia e Estatística - IBGE - [online]. Cidades e Estados. Brasil: IBGE; 2020 [cited 2020 Oct 20]. Available from: http:www.ibge.gov.br/cidades-e-estados/pe/salgueiro.html.

Kenubih A, Dagnachew S, Almaw G, Abebe T, Takele Y, Hailu A, et al. Preliminary survey of domestic animal visceral leishmaniasis and risk factors in north-west Ethiopia. Trop Med Int Health 2015; 20(2): 205-210. http://dx.doi.org/10.1111/tmi.12418. PMid:25327874.

Limeira CH, Alves CJ, Azevedo SS, Santos CSAB, Melo MA, Soares RR, et al. Clinical aspects and diagnosis of leishmaniasis in equids: a systematic review and meta-analysis. Braz J Parasito/ Vet 2019; 28(4): 574-581. http://dx.doi.org/10.1590/s1984-29612019074. PMid:31596317.

Menezes RC, Campos MP, Popielarczyk M, Kiupel M. Cutaneous Leishmaniosis caused by Leishmania martiniquensis in a horse in Florida. J Comp Pathol 2019; 173: 13-18. http://dx.doi.org/10.1016/j.jcpa.2019.09.011. PMid:31812168.

Müller N, Welle M, Lobsiger L, Stoffel MH, Boghenbor KK, Hilbe M, et al. Occurrence of Leishmania sp. in cutaneous lesions of horses in Central Europe. Vet Parasitol 2009; 166(3-4): 346-351. http://dx.doi.org/10.1016/j.vetpar.2009.09.001. PMid:19800739.

Nardoni S, Altomonte I, Salari F, Martini M, Mancianti F. Serological and molecular findings of Leishmania infection in healthy donkeys (Equus asinus) from a canine leishmaniosis endemic focus in Tuscany, Italy: a preliminary report. Pathogens 2019; 8(3): 99. http://dx.doi.org/10.3390/pathogens8030099. PMid:31323973.

Oliveira PM, Garcia F, Evers F, Barbosa VM, Obando DCM, Nasciutti NR, et al. Seroepidemiology of Leishmania spp. in equids from Uberlândia, Minas Gerais, Brazil. Cienc Rural 2017; 47(5): e20160697. http://dx.doi.org/10.1590/0103-8478cr20160697.

Pace, D. Leishmaniasis. J Infect 2014; 69(1): S10-S18. http://dx.doi.org/10.1016/j.jinf.2014.07.016. PMid:25238669.

Platt AR, Woodhall RW, George AL. Improved DNA sequencing quality and efficiency using an optimized fast cycle sequencing protocol. Biotechniques 2007; 43(1): 58-62. http://dx.doi.org/10.2144/000112499. PMid:17695253.

Quaresma PF, Rêgo FD, Botelho HA, Silva SR, Moura AJJr, Teixeira RG No, et al. Wild, synanthropic and domestic hosts of Leishmania in an endemic area of cutaneous leishmaniasis in Minas Gerais State, Brazil. Trans R Soc Trop Med Hyg 2011; 105(10): 579-585. http://dx.doi.org/10.1016/j.trstmh.2011.07.005. PMid:21890159.

R Core Team. R: A language and environment for statistical computing [online]. Vienna: R Foundation for Statistical Computing; 2020 [cited 20 Mar 2021]. Available from: https://www.R-project.org/.

Reuss SM, Dunbar MD, Mays MBC, Owen JL, Mallicote MF, Archer LL, et al. Autochthonous Leishmania siamensis in horse, Florida, USA. Emerg Infect Dis 2012; 18(9): 1545-1547. http://dx.doi.org/10.3201/eid1809.120184. PMid:22932732.

Rohousova I, Talmi-Frank D, Kostalova T, Polanska N, Lestinova T, Kassahun A, et al. Exposure to Leishmania spp. and sand flies in domestic animals in northwestern Ethiopia. Parasit Vectors 2015; 8(1): 360. http://dx.doi.org/10.1186/s13071-015-0976-1. PMid:26152578.

Sgorbini M, Bonelli F, Pizzolli I, Tognetti R, Corazza M. Seroprevalence of Leishmania sp. infection in healthy horses housed in endemic areas in Tuscany. J Equine Vet Sci 2014; 34(4): 572-574. http://dx.doi.org/10.1016/j.jevs.2013.09.009.

Silva JC, Zacarias DA, Silva VC, Rolão N, Costa DL, Costa CHN. Comparison of optical microscopy and quantitative polymerase chain reaction for estimating parasitaemia in patients with kala-azar and modelling infectiousness to the vector Lutzomyia longipalpis. Mem Inst Oswaldo Cruz 2016a; 111(8): 517-522. http://dx.doi.org/10.1590/0074-02760160185. PMid:27439033. 
Silva MAM, Frutuoso MNMA, Rodrigues SSFB, Nogueira RJMC. Fatores socioambientais influenciados pela seca na conservação da Caatinga. Holos 2016b; 32(4): 245-257. http://dx.doi.org/10.15628/holos.2016.4175.

Soares IR, Silva SO, Moreira FM, Prado LG, Fantini P, Maranhão RPA, et al. First evidence of autochthonous cases of Leishmania (Leishmania) infantum in horse (Equus caballus) in the Americas and mixed infection of Leishmania infantum and Leishmania (Viannia) braziliensis. Vet Parasitol 2013; 197(3-4): 665-669. http://dx.doi.org/10.1016/j.vetpar.2013.06.014. PMid:23845306.

Stevenson M, Sergeant E, Nunes T, Heuer C, Marshall J, Sanchez J, et al. epiR: Tools for the Analysis of Epidemiological Data: R package version 1.0-15 [online]. 2020 [cited 20 Mar 2021]. Available from: https://CRAN.R-project.org/package=epiR.

Truppel JH, Otomura F, Teodoro U, Massafera R, Costa-Ribeiro MCV, Catarino CM, et al. Can equids be a reservoir of Leishmania braziliensis in endemic areas? PLoS One 2014; 9(4): e93731. http://dx.doi.org/10.1371/journal.pone.0093731. PMid:24721908.

World Health Organization - WHO. Integrating neglected tropical diseases into global health and development: fourth WHO report on neglected tropical diseases [online]. 2017 [cited 2020 Oct 26]. Available from: https://apps.who.int/iris/bitstream/hand le/10665/255011/9789241565448-eng.pdf;jsessionid=FF58D6943C1C407719FAF54A2A29FA05? sequence=1. 